sekedar mereduksi entitas kesadaran ke dalam proses-proses syaraf tersebut, hanya akan memastikan hilangnya peluang untuk menjelaskan struktur kesadaran manusia secara utuh dan fundamental. Pendekatan alternatif selain model-model neuroscience terhadap gejala-gejala kesadaran ini antara lain diperoleh melalui teori-teori kognisi kontemporer yang berbeda dengan pendekatan sebelumnya dalam hal pene-

\section{Membangun Moti-} vasi Diri Berbasis Pada Nilai Kecerdasan Berbasis Neuroscience: IQ, EQ dan SQ

\author{
Agus Sutiyono \\ Lembaga Pengabdian Kepada Masyarakat UNJ
}

Model-model kecerdasan yang kini dikembangkan dalam dunia Psikologi mendasarkan argumen-argumennya pada temuan-temuan ilmiah dari studi dan penelitian neuroscienc. Mulai dari model kecerdasan konvensional (IQ), kecerdasan emosional (EQ), hingga yang mengklaim diri sebagai model kecerdasan ultimat; kecerdasan spiritual (SQ), seluruhnya masih menjelaskan kesadaran manusia dengan segenap aspek-aspeknya sebagai proses yang secara esensial berlangsung pada jaringan syaraf. Meski jaringan syaraf pusat menampakkan gejala-gejala aktivitaas kesadaran manusia secara dominan, namun kanannya terhadap proses hidup secara keseluruhan,alih-alih memusatkan perhatian terhadap jaringan syaraf pusat saja.Pendekatan ini mengkarakterisasi diri manusia dalam struktur-struktur sistem kompleks metasistemik dengan sifatsifat emergent yang nampak sebagai gejala-gejala kecerdasan.

\section{Pendahuluan}

Studi dan penelitian tentang kecerdasan dalam psikologi modern pada dasarnya termotivasi utnuk memenuhi keperluan-keperluan praktis yaang terkait dengan dunia pendidikan/pekerjaan/kehidupan sehari-hari; yakni untuk memahami, mengukur, megklasifikasi, mengelola serta memanfaatkan aspekaspek kecerdasan individu dalam kehidupannya sehari-hari. Dalam konteks ini, kecerdasan dimaknai sama seperti maknanya dalam bahasa sehari-hari-sebagai kemampuan untuk menyelesaikan persoalan-persoalan praktis (problem - solving capacity).

Seperti yang telah dapat kita terka, dalam perkembangannya kemudian pemaknaan ini terpaksa harus diperluas untuk dapat diletakkan dalam konteks yang lebih fundamental, karena pada 
dasarnya kecerdasan dan aspek kognisi tak terpisahkan dari aktivitas pikiran/kesadaran manusia secara utuh dar hubungannya dengan aspek-aspek kedirian manusia seutuhnya yang belum terjamah, serta interaksinya dengan lingkungan di sekelilingnya. Hanya melalui konteks yang lebih substansial dan integral inilah kita boleh berharap untuk mendekati fenomena kecerdasan \{sekaligus juga pikiran/aktivitas kesadaran) secara lebih komprehensif.

Dalam konteks yang lebih fundamental dan ekstensif ini, pada akhirnya secara tak terelakkan kita berhadapan dengan isu-isu dan pertanyaan-pertanyaan fundamental yang saling terkait erat apakah kecerdasan itu? Bagaimana ia bekerja? Bagaimana kita dapat memahami sesuatu? Objek atau proses apa yang terlibat pada saat kita berfikir? Bagaimana bisa berkesadaran? Kapan kesadaran muncul? Apa fungsinya? Apa peran kesadaran dalam eksistensi manusia yang masih sangat baru ini? Apa kaitannya dengan lingkungan? Bagaimana hubungan antara kesadaran dengan alam semesta? Di manakah batas-batas aspek kedirian manusia itu? Bisakah selain manusia berfikir dan berkesadaran? Dari mana kesadaran berasal?

Isu dan pertanyaan yang selalu aktualdan penting inj telah menjadi sumber khazanah berbagai ikhtiar manusia yang termanifestasi dalam berbagai bidang kajian/penyelidikan yang saling terkait erat satu sama lain dan tak terpisahkan - hanya terbedakan melalui abstraksi formal-mulai dari filsafat, psikologi, antropologi, cognitive science, linguistik, neuroscience, yang juga melibatkan ilmu-ilmu alam dasar seperti biologi, kimia, fisika, dengan bahasa matematika, hingga computer science dan artificial intellegence. Semua isu tadi didekati dengan berbagal motivasi dimensi, kerangka kerja serta nuansa berbeda yang mewarnai masing-masing ikhtiar keilmuan yang beragam tadi.

Meski manfaat dari masing-masing bidang tadi secara independen telah membuka cakrawala peradaban dan meningkatkan kualitas hidup kita, namun hanya melalui visi dan konteks yang menyeluruhlah kita dapat mengintegrasikan seluruh kontribusi bidang-bidang tadi ke dalam sebuah bangunan kerangka kerja yang utuh dan koheren, guna memperoleh pengetahuan yang komprehensif tentang manusia secara utuh dan menurunkan strategi yang benar untuk mengembangkan potensi insaniah secara utuh dari setiap individu dalam masyarakat. Pada akhirnya, secara praktis semuanya terkait lagi dengan motivasi awal yang telah diungkapkan sebelumnya.

Satu catatan penting lain berkaitan dengan isu-isu tadi, yakni kenyataan bahwa seluruh isu-isu dan pertanyaan-pertanyaan tadi juga diamati - secara luar biasa lengkap dan terperinci- oleh risalah-risalah kenabian yang pernah diturunkan di sepanjang sejarah umat manusia dalam berbagai titik waktu. tempat dan tradisi yang berlainan, sebagai suatu isu sentral dalam risalah tersebut. Namun berbeda dengan ikhtiar-ikhtiar ilmiah tadi, risalah-risalah kenabian nampaknya tidak hadir dengan 'jawab$a n^{\prime}$ atas isu-isu tadi. Lebih dari itu, 
risalah-risalah ini hadir sebagai sebuah struktur realitas ultimat terhadap eksistensi insaniah yang sejati, yang menyentuh dan menyelesaikan isu-isu tersebut tanpa perlu memberi jawaban. Karena batasbatas diri manusia bukanlah terletak pada apa-apa yang kita pikirkan tentang diri kita, maka pertanyaan yang muncul dalam fakultas pikiran kita - serta jawaban yang juga terkait dengannya- tidak relevan lagi ketika struktur realitas tersebut sudah menempatkan diri manusia dalam konteksnya yang sejati. Itulah sebabnya dalam risalah-rsalah kenabian, pengetahuan tidak dapat dipisahkan dari segenap jalan kehidupan pengikutnya yang menjadi perwujudan hidup dari risalah itu sendiri. Jadi dalam hal ini - seperti halnya materi adalah energi- pengetahuan adalah transformasi. Di sinilah letak perbedaannya dengan ikhtiar ilmiah yang dapat tetap saja menjadi abstrak dan teoritik.

Ketertarikan manusia terhadap fenomena kecerdasan - lebih luas lagi; fakultas pikiran dan aktivitas kesadaran dirinya sendiri- telah dimulai sejak lama, barangkali sejak kesadaran itu sendiri muncul. Untuk memahami bagaimana fakultas kesadaran itu dimaknai kini (dan untuk menentukan arah-arah investigasinya nanti) kita dapat menelusuri landasan-landasan filosofis yang mendasarinya. Tentu saja tradisi filsafat baratlah yang melandasi hal ini, sebagaimana tradisi itu pulalah yang melandasi alam pikiran kita di sebuah negeri Timur dengan gaya pendidikan yang sedikit membarat dan kehilangan seluruh identitas substansialnya. Cukup memadai kiranya untuk mengawali penelusuran konsep kecerdasan dalam tradisi filsafat Barat melalui para filsuf Yunani; Socrates, Plato dan Arsitoteles, meskipun para filsuf pra-sokratik lainnya juga telah menyentuh aspek-aspek ini. The safest characterization of the European philosophical tradition is that it consists of a series of footnotes to plato," demikian A.N. Whitehead menjaminnya.

Dalam Eutyphron, Plato mengungkapkan sebuah dialog ketika Socrates bertanya pada Eutyphron, "Aku ingin tahu apa yang merupakan karakteristik dari kesalehan (piety, ada pula yang menterjemahkannya dengan goodness/kebaikan) yang membuat seluruh tindakan menjadi saleh ... yang dapat aku rujuk dan aku pergunakan sebagai pedoman untuk menilai tindakantindakanmu dan tindakan-tindakan orang lain." Dengan kata lain, Socrates menanyakan suatu alogaritma yang membedakan antara pikiran dan perbuatan yang saleh/ baik, dari pikiran dan perbuatan yang tidak saleh/tidak baik, dengan ini ia sekaligus mendefinisikan kecerdasan bersahaja namun dengan makna yang dalam. Aristoteles kemudian mengerjakan pekerjaan rumahnya ini dengan memformulasikan seperangkat kaidah-kaidah formal yang mengatur alur penalaran pikiran rasional yang saleh sebagai apa yang kemudian kita sebut logika. Aristoteles mengembangkan sebuah sistem silogisme formal untuk alur penalaran yang valid, yang setara prinsip memungkinkan seseorang untuk memperoleh kesimpulan yang benar dari premis-premis awalnya. 
Nampak jelas di sini bahwa gagasan tentang kecerdasan yang merupakan kemampuan untuk berfikir dan melakukan tindakan-tindakan yang benar/saleh -dalam konteks praktis: problem-solving capacity - dirumuskan dalam kemampuan untuk berfikir menurut kaidah-kaidah formal penalaran yang baik: kemampuan untuk berpikit logis, Tapi pekerjaan rumah Aristoteles tidak berhenti di sini. karena ia pun meyakini adanya suatu fakuitas penalaran intuitif dalam diri manusia, yang juga saleh tapi tidak dalam konteks logikanya. Kita merasakan adanya sebuah reduksi nuansa makna dalam yang kemudian berlanjut hingga peradaban modern ini karena kesalehan dalam pertanyaan Socrates agaknya tidak hanya dalam nuansa praktis (saleh dalam pengertian misalnya ketika menyeberang lihat kirikanan, ketika ada ancaman menghindar, ketika ada sesuatu merespon dengan sesuatu itu dengan tepat, dil.) namun juga dalam nuansa lain yang tidak dapat kita temukan hanya melalui pengelaborasian sist eksistensi manusia saja.

\subsection{Q, EQ dan SQ}

Memasuki abad ke-20 kita mengenal sebuah istilah populer yang berkaitan dengan kecerdasan IQ. Intelligent Qwotient. Sekarang ini hampir sulit menemukan ada istilah lain selain IQ yang demikian sangat mempengaruhi seseorang dalam memandang diri mereka sendiri dan orang lain. Adalah psikolog berkebangsaan Prancis, Alfred Binet, yang pada tahun 1905 menyusun suatu test kecerdasan terstandarisasi untuk pertama kalinya. Ber- beda dengan bagaimana IQ diposisikan kini dalam cara masyarakat memandang dan mengklasifikasikan individu-individu, pada awalnya Binet justru merancang test kecerdasannya ini untuk mengidentifikasi pelajar-pelajar di sekolahnya saat itu yang membutuhkan bantuan khusus, dan bukannya untuk mencari anak-anak yang berbakat luar biasa seperti yang berlangsung di kemudian hari. Lebih jauh lagi Binet berusaha untuk memastikan bahwa anak-anak yang memiliki persoalan-persoalan dalam perilaku ini tidak lantas dianggap secara terburu-buru hanya sebagai orang yang bodoh/tidak cerdas.

Test yang dikembangkan oleh Binet ini tidak.lama kemudian disusun kembali oleh Lewis Terman, seorang profesor dalam bidang psikologi dari Stanford University di US. Terman menggagaskan untuk memformulasikan suatu skor nilai yang disebutnya sebagai IQ -Intelligent Quotient-yang diperoleh dengan membagi 'umue mental' seseorang (yang didapat dari test kecerdasan Binet) dengan umurnya yang sebenamya atau umur kronologisnya.

Sekarang metoda test IQ masih digunakan terutama -seperti yang pertama kali diharapkan oleh Binet - untuk keperluan membantu para pelajar yang membutuhkan pelajaran tambahan dan perhatian ekstra. Namun sejarah membuktikan bahwa metoda ini bergerak lebih jauh lagi dalam mempengaruhi aspekaspek pemikiran masyarakat modern dalam cara mereka memandarg aspek-aspek potensi individu. Barangkali tidak ada yang salah dengan metoda penentuan IQ ini, 
namun peradaban modern Barat ketika itu (dan hingga kini) tidak memiliki konsepsi yang utuh dalam memandang diri manusia. Wajar jika saat itu IQ yang merefleksikan kemampuan seseorang dalam menghadapi situasi-situasi praktis dalam hidupnya (aspek kecerdasan sebag ai problem-solving capacity), dianggap sebagai satu-satunya atribut kemanusiaan yang paling berharga. Pandangan int juga dipengaruhi oleh perkembangan teori kecerdasan abad ke 19 - panduan antara sains dan sosiologi- yang dipelopori oleh sepupu Charles Darwin, Francis Galton, pada akhir abad ke 19 secara terpisah dari apa yang dikerjakan Binet saat itu. Galton juga meyakini bahwa jika orangorang yang memiliki banyak atribut kecerdasan ini dapat dildentifikasi dan diletakkan dalam jabatanjabataan kepemimpinan yang strategis, maka seluruh lapisan masyarakat akan memperoleh manfaatnya. Ketika itu juga berkembang paham pugenics -populer di Eropa dan US sebelum akhirnya Hitler menyadarkan mereka betapa mengerikannya gagasan itu- yang meyakini bahwa kecerdasan pada umumnya diwariskan lewat garis keturunan dan oleh karena itu orang-orang yang kurang cerdas harus didorong agar tidak melakukan reproduksi. Gerakan ini juga menggunakan IQ sebagai metoda justifikasinya.

Dalam risetnya di Stanford, Termant memberikan usulan - yang kemudian diterima secara luas di US saat itu-bahwa test $1 Q$ selayaknya digunakan untuk melakukan seleksi populasi sehingga para pemuda dapat ditempatkan berdasarkan nilai
IQ-nya di dalam sistem akademik dengan derajat-derajat kelas tertentu, yang pada akhirnya akan mengarahkan mereka pada posisi dan status sosial-ekonomi yang setaraf pula di masa depannya. Andaikan kita sedemikian pandainya dengan nilal test IQ tertinggi 1\% dari seluruh warga US, maka pemerintaah US akan sangat pandai juga dan dermawan dalam ha] mencarikan dan menawarkan kita akses menuju jenjang pendidikan kelas satu di sana, dan akhirnya pula menuju kesempatan-kesempatan kerja dan posisi-posisi sosial yang bertaraf tinggi. Orang-orang dengan $1 Q$ tinggi di sana tidak selalu memimpin jabatan penting dalam pemetintahan; namun dapat dipastikan mereka memiliki akses atas posisi-posisi istimewa dan hak-hak khusus Lainnya. Dalam istilah kontemporer, suatu negara yang mengorganisasikan dirinya berdasarkan nilai test $1 Q$ sepeti di US disebut meritokrasi (merit: jasa/guna).

Meritokrasi $\rightarrow$ yang jika diterjemahkan dalam prasangka baikpada dasarnya bertujuan untuk mengaktualisasikan dan mengoptimalkan potensi-potensi setiap warga negaranya demi kepentingan bersama, karena satu dan lain hal, menyebabkan terbentuknya kelaskelas status sosial serta memperlebar jurang antar kelas. Ironis sekali bahwa gagasan yang pada dasarnya cukup baik ini, terpaksa harus membatasi kesempatan banyak orang hanya karena potensi-potensi mereka tidak diukur oleh metoda test kecerdasan konvensional- test IQ. Hal ini melahirkan gelombang gerakan protes dan kritik dari berbagai kalangan, yang sebenamya telah 
bermula sejak gagasan IQ diterima kalangan luas. Gerakan anti-1Q yang paling signifikan terjadi di Inggris sekitar tahun 60-an. Ketika itu, mengadopsi sistem seleksi berbasis IQ yang ketat bagi anak-anak berumur belasan tahun yang masuk ke sekolah-sekolah negeri. Gerakan ini secara umum tidak ditujukan pada metoda itu sendiri, namun pada penerapannya yang kurang bijaksana. Jadi secara konseptual. masyarakat luas tetap menyadari arti penting aspek kecerdasan ini sebagat satu-satunya aspek yang dominan dalam mengkatakterisasi diri manusia. Kritik terhadap IQ sendiri tidak menjadi pendorong yang utama untuk gerakan anti-IQ yang justru semakin meluas memasuki dekade berikutnya. Bahkan pada tahun 1971 US Supreme Court telah memutuskan untuk menghapuskan penggunaan metoda test $1 Q$ untuk masalah-masalah perekrutan dan kepegawaian, kecuali dalam kasus-kasus tertentu.

Yang perlu ditekankan di sini bukanlah pada betapa test IQ itu ternyata kurang efektif dalam menyeleksi orang berdasarkan aspek kecerdasannya saja, namun pada betapa konsep kecerdasan ini telah membentuk konsepsi diri manusia yang parsial dan reduksionistik sebagai akibat dari ketiadaan konsep diri manusia seutuhnya dalam tradisi filosofis dan budaya barat yang berlaku saat itu hingga kinı. Barangkali akan lain halnya, jika konsep dan metoda test kecerdasan IQ ini muncul dalam tradisi filosofis yang memandang potensipotensi diri manusia secara utuh. Besar kemungkinannya gagasan IQ ini akan melengkapi konsepsi inte- gral yang ada ke dalam sebusah kerangka kerja yang koheren dengan seuah metoda praktis yang akan bermanfaat dalam memahami dan menyelidiki fenomena kesadaran manusia lebih jauh lagi. Meski respon kritis secara teoritik atas penaksiran kecerdasan berbasis IQ ini telah muncul sejak bermula awal kelahirannya, namun baru satu dekade akhir abad ini kita mengenal suatu rumusan-rumusan psikologi populer yang mengemas kontribusikontribusi studi dan riset dari para penyelidik kecerdasan sebelumnya dengan cukup baik. Dalam awal tahun 1990-an kita mengenal istilah Emotional Quotient diusulkan oleh Daniel Goleman. Belakangan in menjadi populer pula istilah Spirithal Quotient yang diusulkan oleh pasangan Danah Zohar dan Ian Marshall. Meski secara esensial tidak terdapat sebuah terobosan ilmiah yang betul-betul baru dalam gagasan-gagasan mereka ini, namum para pakar ini telah berhasil mensintesakan, mengemas dan mempopulerkan seklan banyak studi dan riset terbaru di barbagai bidang keilmuan ke dalam sebuah formulasi yang cukup populer untuk menunjukkan bahwa aspek kecerdasan manusia ternyata lebih luas dari sekedar apa yang semua biasa kita maknai dengan kecerdasan.

Goleman mempopulerkan pendapat para pakar teori kecerdasan bahwa ada akpek lain dalam diri manusia yang yang berinteraksi secara aktif dengan aspek kecerdasan yang konvensional tersebut. la menyebutnya dengan istilah kecerdosan emosional dan mengkaitkannya dengan kemampuan untuk mengelola perasaan, yakni kemampuan untuk 
mempersepsi situasi, bertindak sesuai dengan persepsi tersebut, kemampuan untuk berempati, dll. Jika kita tidak mampu mengelola aspek rasa kita dengan baik, maka kita tidak akan mampu untuk menggunakan aspek kecerdasan konvensional kita (IQ) secara efektif, demikian menurut Goleman. Sementara itu Zohar dan Marshall mengikutsertakan aspek konteks nilai sebagai suatu bagian dari proses berfikir/ berkecerdasan dalam hidup yang bermakna, untuk ini mereka mempergunakan istilah kecerdasan Spiritual (SQ). indikasi-indikasi kecerdasan spiritual ini dalam pandangan mereka meliputi kemampuan untuk menghayati nilai-nilai dan maknamakna, memiliki kesadaran diri, fleksibel dan adaptif, cenderung untuk memandang sesuatu secara holistik, serta berkecenderungan untuk mencari jawaban-jawaban fundamental atas situasi-situasi hidupnya, dll. Sebagai konsekuensi melibatkan konteks nilai dan makna dalam aspek berkecerdan manusia, maka SQ sebetulnya mengamati pelik-pelik ontologis dan epistemologis dalam mencermati aspekaspek kecerdasan/kesadaran diri manusia secara utuh. Di sini barangkali kita bisa berharap akan adanya sebuah sintesa bangunan kerangka kerja yang koheren dan konprehensif untuk mendekati konsepsi diri manusia dengan segenap aspekaspeknya yang terpisahkan, meskipun pada kenyatannya Zohar tidak menyelesaikan masalah ini dengan cukup terperinci dan lebih memusatkan perhatiannya pada aspekaspek aplikasi praktisnya.

Namun EQ dan SQ ini pun pada dasarnya tidak banyak membantu kita - yang telah terbiasa memahami apa-apa yang ebrlangsung di dalam benak kita dalam istilahistilah intelegent dan quotient-seandainya kita tidak memiliki visi yang fundamental dan menyeluruh dalam memandang aspek-aspek kedirian manusia secara utuh. Kita menyadari bahwa gelombang antusiasme yang berlebihan terhadap kedua formulasi kecerdasan ini alihalih bermanfaat, mungkin malah berbalik membatasi dan mematikan banyak aspek dan potensi manusia yang belum terjamah. Di sisi lain, kita dituntut untuk sedapatnya memanfaatkan formulasi kecerdasan ini dalam rangka membangun sebuah konsepsi manusia yang utuh, radikal dan fundamental serta menerjemahkannya secara strategis dalam langka-langkah praktis agar dapat mengatasi masalah aktual di negeri kita.

\section{Neuroscience dan Kesadaran Ma- nusia}

Seperti telah terungkap di atas, secara umum EQ dan $\mathrm{SQ}$ memiliki kesepakatan untuk memandang aspek-aspek kecerdasan manusia lebih dari sekedar aspek kognitif konvensional yang terukur dengan metoda test IQ. Keduanyapun samasama dirumuskan berdasarkan hasil-hasil penelitian dalam bidang psikologi dan neuroscience terbaru, yang semakin berkembang terutama akibat kemajuan teknologi instrumentasi kedokteran yang dapat mengamati aktivitas-aktivitas vital sistem syaraf pusat dan organ-organ lainnya dengan metoda visualisasi yang cukup canggih. Hasil-hasil penelitian ini, terutama dalam bidang neuroscience, digunakan sebagai ba- 
sis untuk mendukung formulasiformulasi EQ dan SQ. sementara EQ merujuk pada menemuan-penemuan penting dari Joseph LeDoux tentang fungsi organ amigdala pada batang rongga otak, maka SQ merujuk pada hasil-hasil penelitian terutama dari Rudolfo Llinas tentang proses-proses gelombang elektromagnetik (Electroencephalogram dan magnetoencephalogram) syaraf pusat yang berfungsi sebagai pengintegrast persepsi.

LeDoux mengamati bahwa gejala-gejala emosi yang sebelum. nya dianggap berlangsung sebagai akibat dari aktivitas-aktivitas fungsional ofak besar, neokorteks dan sistem limbik, ternyata sebagian besar berlangsung pula sebagai akibat dari organ amigdala yang terletak di bagian dalam tengah otak kita. Dalam eksperimennya, LeDoux mengamati bahwa organ ini mengalami peningkatan aktivitas seiring res: pon-respon inderawi dari luar (misalnya retina mata kita yang menerima cahaya/objek visual dan mengaktifkan syaraf optik), maka impuls syaraf in akan diterima oleh. Thainmus - sebuah bagian di dalam otak yang menerjemahkan stimuli impuls syaraf menjadi bentuk-bentuk yang dipahami oleh otak - untuk kemudian diterima oleh ineokorteks dan korteks visual yang mengolahnya dan merangsang amigdala apabila stimulinya bersifat emosional. Namun ternyata menurut LeDouex, sebagian besar sinyal semula dari thalamus ini langsung menuju amigdala tanpa melewati neokorteks/tanpa melalui proses konvensional, dengan transmisi yang lebih cepat sehingga memungkinkan terjadinya respon yang lebih cepat (meskipun relatif kurang akurat). Jadi LeDoux meyakini bahwa amigdala dapat memicu suatu respon-respon yang terkait dengan aktivitas emosional sebelum otak besar kita memahami betul apa yang terjadi, bahkan lebih jauh lagi sis tem emosi ternyata dapatbekerja sendiri tanpa partisipasi kognitif: perasaan memiliki kecerdasannya sendiri. Bukti ilmiah inilah yang dijadikan sebagai pendukung argumentasi Goleman bahwa EQ adalah syarat utama penggunaan IQ secara efektif, yang kemudian mengkaitkan beberapa sikap mental tikika! yang terkait dengan EQ - kesadar. an untuk memahami perasaan diri sendiri sendiri dan orang lain, empati, kasih sayang, motivasi, serta kemampuan untuk merespon secara wajar atas situasi-situasi bahagia atau sedih.

Kesadaran pada saat tertidur dan terbangun serta pengikatan peristiwa-peristiwa kognitif dalam otak.

\section{Teori Kognisi Kontemporer}

Dalam teori kontemporer tentang sistem-sistem hidup, pikiran/ kesadaran bukanlah sebuah objek atau entitas benda, namun sebuah proses. Proses ini adalah proses kognisi-proses untuk memahamiproses kecerdasan, yang teridentifikasi dengan proses kehidupan itu sendiri. Teori kontemporer ini dikenal dengan sebutan Teori Kognitif Santiago; yang digagaskan oleh Humberto Maturana dan Fransisco Varela, dari Universitas Santiago, Chili.

Hubungan antara pikitan, atau kognisi dengan proses hidup, merupakan hal yang sama sekali baru 
dalam dunia sains modern, namun telah lama dikenal dalam tradisitradisi lama. Peradaban pramodern dalam berbagai tradisi kebudayaannya memandang bahwa kesadaran rasional/pikiran manusia hanyalah satu aspek dari jiwa manusia sejati yang immateri. Oleh karena itu, dikotominya yang paling mendasar tidak terletak antara tubuh (body) dengan pikiran ( $n$ tind), namun antara tubuh (body) dengan jiwa (soul) atau tubuh (body) dengan ruh (spirit), Perbedaan antara jiwa dengan ruh berfluktuasi di setiap zaman dan hampir dianggap tidak signifikan lagi perbedaannya pada masa kini. Namun, perlu diperhatikan bahwa bahasa-bahasa peradaban pramodern yang sangat ketat dalam menggunakan kata (berbeda halnya dengan era posmodern kini), membedakan kedua istilah jiwa dan ruh ini. Misalnya dalam rumpun bahasa Yunani (psydhe-pnenma), Latin (anima-spiritus), Smith (nafsruh), Sansekerta (atman), Timur Jauh (c)hi), dll. Meskipun secara etimologis kedua istilah untuk jiwa dan ruh ini memiliki nuansa yang dekat (nafs, hidup) dua istilah ini secara umum membawakan dua Sistem "Kognisi" emosional yang dijelaskan oleh LeDoux terjadi melalui aktivitas-aktivitas fungsional organorgan syarat pusat di kepala kita, terbentuk dari suatu interaksi paralel dari ratusan ribu jalinan sel syaraf yang terhubung dan bekerja secara paralel dalam suatu kumpulan jaringan syaraf yang amat masif. Jaringan syaraf inilah yang melasdasi dinamika sistem emosional sebagaimana yang diungkapkan oleh Goleman. Menurutnya, jaringan yang bekerja secara paralel ini berlanggung jawab terhadap aspek- aspek kecerdasan emosional yang seluruhnya terkait dengan dorongan-dorongan perasaan, pembentukan kebiasaan/habituasi, dan pengenalan pola-pola. Mekarisme syaraf yang paralel ini melengkapl mekanisme lintasan-lintasan jalur syaraf yang terhubung secara serial yang memungkinkan otak besar kita untuk menelusuri aturan-aturan, untuk berfikir secara logis dan rasional, dan sekuensial yakni aspekaspek kognisi yang biasa kita kaitkan dengan kecerdasan 10.

Namun tentu saja, aktivitas kecerdasan dan kesadaran manusia tidak hanya terbentuk dari meka* nisme serial dan paralel yang terpisah seperti ini saja, karena kedua mekanisme ini sendiri bekerja secara bersama-sama dalam satu kesatuan kesadaran yang berpusat di otak. Bagaimana kedua bentuk organisasi syaraf serial dan paralel yang selalu terpisah ini bisa membentuk sebuah persepsi dan kesadaran yang utuh dikenal dengan nama "binding problem". Persoalan ini pertama kalinya didekati oleh ahli syaraf dari Austria, Wolf Singer, pada pertengahan tahun 1990-an. Singer berhasil menunjukkan bahwa terdapat suatu proses syaraf yang berlangsung dalam otak yang didedikasikan untuk menyatukan pengalaman-pengalaman yang terpisah serta memberikannya suatu konteks makna. Sebelum hasil penelitian Singer tentang gelombang syaraf sinkron yang menyatukan mekanisme syaraf seluruh otak ini, para ahli syaraf dan Cognitive Scientist hanya mengenali dua bentuk organisasi dalam susunan syaraf pusat kita. Belakangan kemudian hasil penelitian Singer ini dikem- 
bangkan oleh Rudolfo Llinas dengan meneliti aktivitas gagasan yang berbeda, yakni aktivitas kesndaran emosional manusia dengan daya hidup manusin.

Gagasan intuitif yang mendasari penggunaan istilah-istilah dan konsep-konsep dalam kebudayaan pramodern ini adalah bahwa ruh sebagat nafas kehidupan. Serupa dengan itu pula, maka konsep kognisi dalam teori Santiago melampaui kognisi sebagai pikiran rasional karena teori ini melibatkan segenap proses hidup. Jelas bahwa dalam teori kognisi baru ini kita berhadapan dengan suatu ekspansi radikal atas konsep-konsep konvensional yang mendasari $\mathrm{IQ}$, EQ dan SQ yang mendasarkan aspek kecerdasan dan kesadaran manusia pada aktivitag-aktivitas otak sebagai organ komputasional. Dalam pandangan teori kognisi Santiago ini, kognisi melibatkan seluruh proses hidup -bahkan proses kognisi tidak memprasyaratkan adanya otak ataupun sistem syaraf. Dalam hal ini bahkan bakteria pun dapat mempersepsi karakteristik-karakteristik tertentu dalam lingkungan mereka. Bakteria ini dapat merasakan perbedaan kimiawi di sekeliling mereka, dan berenang menuju larutan gula dan menghindari panas, menjauhi atau mendekati sinar matahari, bahkan beberapa jenis bakteria dapat mendeteksi medan magnetik: sebuah bentuk perilaku yang cerdas.

Teori kognisi Santiago berakar pada konsep cybernetics yang pertama kali digagaskan oleh Norbert Wiener pada tahun 1948. Kata itu sendiri didefinisikan langsung dalam judul buku yang ditulis sendiri oleh Wiener, Cybernetics; Control and Communication in Animal and the Machine. Konsep ini berkembang dalam suatu gerakan intelektual yang berupaya mendekati pengkajian ilmiah atas kesadaran manusia dan ilmu pengetahuan dari suatu prespektif sistemik dan interdisipliner yang melampaui kerangka kerja psikologi dan epistemologi tradisional. Pendekatan ini dalam bidang psikologi secara bebas seringkali diistilahkan sebagai cognitive science (sains kognitif).

Cybernetics berkontribusi terhadap bidang sains kognitif dengan model kognisi konvensionalnya yang pertama. Salah satu premis dari model ini adalah bahwa kecerdasan manusia menyerupai 'gejala kecerdasan' yang dimiliki oleh kom. puter pada suatu tingkatan dimana kognisi dapat didefinisikan sebagai sistem pengolahan informasi, yakni sebagai manipulasi simbol-simbol yang didasarkan pada sekumpulan aturan-aturan tertentu. Berdasarkan model ini, proses kognisi melibatkan suatu konsep yang disebut sebagai representasi mental. Seperti halnya sebuah komputer, pikiran dimodelkan sebagai sesuatu yang bekerja dengan cara memanipulasi simbolsimbol yang merepresentasikan ciri tertentu dari dunia luarnya. Aktivitas mental yang termodelkan sebagai komputer ini mendominasi seluruh penelitian dalam bidang sains kognitif selama lebih dari tiga puluh tahun. Model kecerdasan IQ sepenuhnya dijelaskan dalam term-term model sains kognitif ini, demikian juga halnya dengan model-model kecerdasa EQ dan SQ secara umum.

Gagasan bahwa otak adalah suatu organ pengolah informasi 
telah mempengaruhi hampir seluruh penelitian dalam bidang nuerobiologi. Sebagai contoh, dalam salah satu penelitian tentang visual korteks (salah satu bagian dari korteks otak yang bertanggumg jawab terhadap sensasi visual) nampak bahwa beberapa sel syaraf tertentu merespon ciri-ciri tertentu dari objek yang sedang diamati kecepatan, warna, kontras, dll. Sel-sel syaraf yang memiliki kekhasan ini dianggap mengambil suatu informasi tertentu dari retina, untuk dilewatkan ke daerah otak lainnya untuk diproses lebih lanjut. Namum dalam penelitian selanjutnya, nampak jelas bahwa percobaan sebelumnya yang menunjukkan kaitan antara sel-sel syaraf tertentu dengan karakteristik khusus tertentu hanya dapat didemonstrasikan pada hewan-hewan percobaan yang terbius dan dalam kondisi-kondisi lingkungan internal dan eksternal yang sangat terkendali. Namun jika percobaan dilakukan pada hewan dalam kondisi biasa dalam ling. kungan yang tipikal, respon-tespon syarafnya menjadi lebih sensitif terhadap konteks rangsangan visual secara keseluruhan dan tidak dapat lagi dinterpretasikan dengan penjelasan-penjelasan pengolahan informasi yang bertahap secara sekuensial.

Model komputer atas otak manusia ini mulai diragukan terutama selelah dikenalnya konsep autopoisesis/self-organizing -diajukan oleh Maturana pada tahun 1970 an- yang memberikan alternatif lain terhadap model sains kognitif terhadap otak manusia ini. Self-organization adalah karakteristik yang paling esensial dari organisme hidup, Karakteristik ini menggambarkan kemampuan suatu sistem hidup untuk mengorganisasikan komponen-komponen subsitemnya secara mandiri dalam kaitan interaksinya dengan struktur internal dan lingkungan sekitarnya. Seluruh gagasan baru ini memunculkan keraguan baru terhadap model komputasional dari organ otak manusia yang secara umum diakibatkan oleh dua masalah besar dalam model ini. Masalah yang pertama adalah bahwa model otak sebagai pusat pengolah informasi yang bekerja secara sekuencial atau setahap demi setahap dalam suatu kurun waktu, dan masalah yang kedua adalah bahwa fungsi-fungsi tertentu teriokalisasi dalam daerahdaerah otak tertentu pula. Kedua karakteristik dalam model ini sangat bertentangan dengan observasi-observasi ilmiah kontemporer terhadap otak manusia. Proses-proses visual yang dilakukan oleh serangga yang paling primitif pun, ternyata jauh lebih cepat daripada apa yang mungkin dikerjakan oleh modelmodel komputasional secara sekuensial; dan otak manusia ternyata tidak tergradasi fungsinya secara signifikan apabila ada salah satu bagiannya yang tidak berfungsi dengan baik. Kedua contoh sederhana ini mengajukan keberatan terhadap model komputasional sekuensial tadi.

Hasil-hasil observasi ini mengusulkan adanya suatu pergeseran perhatian dari manipulasi simbol ke konektivitas antar subsistem, dari aturan-aturan tokal ke koherensi global, dari pengolahan informasi ke sifat-sifat emergent dari jaringan syaraf. Perkembangan dan minat 
penelitian dalam bidang matematika nonlinear dan model-model sistem kompleks belakangan ini, memungkinkan hasil-hasil temuantemuan ilmiah untuk dielaborasikan lebih lanjut guna menemukan struktur-struktur matesistemik pada gejala-gejala yang emergent dalam aspek kesadaran manusia.

Teori kognisi Santiago pada awalnya berasal dari serangkaian penelitian terhadap jaringan syaraf dan juga terkait erat dengan konsep self-organizing dari Maturana, 'sistem-sistem hidup adalah sistem-sistem kognitif' dan 'hidup sebagai suatu proses adalah suatu proses kognisi'. Lebih jauh lagi, teori ini menggagaskan suatu fenomena yang mendasari proses kognisi yang disebut sebagai penggabungan struktural. Sistem autopoietik/self-organizing mengalami perubahan struktural yang berkelanjutan sementara melestarikan pola organisasinya yang terjalin satu dengan yang lain. Suatu sistem hidup tergabung dengan lingkungannya secara struktural, yakni melalui interaksi-interaksi yang berulang, yang pada setiap waktunya memicu perubahan-perubahan struktural dalam sistem. Namun, menurut Maturana, sistem hidup adalah sistem yang otonom. Lingkungan hanya memicu perubahan-perubahan struktural; lingkungan tidak mengarahkan atau menginstruksikan perubahan-perubahan ini.

Sistem-sistem hidup tidak sekedar mengarahkan dan mengkarakterisasi perubahan-perubahan struktural ini, namun juga menginstruksikan gangguan-gangguan mana dari lingkungan yang boleh memicu terjadi perubahan-peru- bahan dalam struktur dirinya. Hal ini merupakan salah satu gagasan kunci dari teori kognisi Santiago. Perubahan struktur dalam suatu sistem adalah suatu perilaku kognisi. Dengan menentukan gangguangangguan mana dari suatu lingkungan yang memicu perubahannya, maka sistem ini mengkreasi dunianya sendiri. Kognisi, karena ia bukanlah merupakan sebuah representasi dari dunia independen yang ada di luar suatu sistem, namun merupakan sebuah proses penciptaan dunia secara terus menerus melalui proses hidup. Interaksi dari suatu sistem hidup dengan lingkungannya adalah interaksi kognitif, sebagaimana proses hidup itu sendiri adalah proses kognitif.

Seperti telah diungkapkan dalam contoh tentang bakteria di atas, jelas bahwa konsekuensi dari teori kognisi Santiago ini mengakibatkan sebuah pergeseran yang radikal dalam hal konsep tentang kognisi dan dengan sendirinya pula konsep tentang kesadaran. Dalam pandangan teori kognisi kontemporer ini, kognisi melibatkan seluruh proses hidup-proses yang berlangsung sebagai akibat dari dua entitas: materi biologis dan nyawa, atau jasad dan ruh-dalam segenap proses persepsi, emosi, perilaku, dll. dengan tidak memprasyaratkan adanya sistem jaringan syaraf ataupun organ otak. Seperti pada kasus bakterium tadi yang memiliki jasad dan nyawa, ia mempersepsi karakeristik tertentu di lingkungan tempatnya hidup: ia menciptakan dunianya sendiri. Ia menginderai gradien perbedaan kimiawi di sekitarnya, dan berprilaku cerdas dengan berenang mendekati larutan 
glukosa dan menghindari larutan asam; ia merasakan dan menghindari panas, bergerak menjauhi atau malah mendekati cahaya, dan pada beberapa jenis bakteria bahkan mendeteksi medan magnetik bumi. Bakterium ini menciptakan dunianya sendiri, dunia terang dan gelap, dunia hangat dan dingin, medan magnetik dan gradien kimiawi.

Jangkauan interaksi yang dimiliki oleh suatu sistem hisup dengan lingkungannya, mendefinisikan domain kognitifnya. Seiring dengan bertambahnya level kompleksitas organisme hidup, demikian pula domain kognitifnya. Organ otak dan sistem jaringan syaraf pada manusia menunjukkan suatu ekspansi yang signifikan atas domain kognitif suatu organisme. Pada level kompleksitas seperti pada manusia, penggabungan struktural ini tidak hanya terjadi dengan lingkungannya namun juga dengan dirinya sendiri, oleh karena itu tidak hanya menciptakan dunia yang terkait dengan lingkungan eksternal, namun juga dengan lingkungan internalnya. Pada manusia, perpaduan struktural yang terkait dengan lingkungan internal ini berkaitan erat dengan gejala-gejala kebahasaan, pikiran, dan kesadaran. 